\title{
Scanning micro-X-ray fluorescence elemental mapping: A new tool for the study of laminated sediment records
}

\author{
T. M. Shanahan \\ Institute for the Study of Planet Earth and Department of Geosciences, University of Arizona, Tucson, Arizona 85721, \\ USA
}

Now at Marine Chemistry and Geochemistry, Woods Hole Oceanographic Institution, Woods Hole, Massachusetts 02543,USA (tshanahan@whoi.edu)

\section{J. T. Overpeck}

Institute for the Study of Planet Earth and Department of Geosciences, University of Arizona, Tucson, Arizona 85721, USA

\section{J. B. Hubeny}

Department of Geology, Salem State College, Salem, Massachusetts 01970, USA

\section{J. King}

Graduate School of Oceanography, University of Rhode Island, Narragansett, Rhode Island 02882, USA

\section{F. S. Hu}

Departments of Plant Biology and Geology, University of Illinois, Urbana, Illinois 61801, USA

\section{K. Hughen}

Marine Chemistry and Geochemistry, Woods Hole Oceanographic Institution, Woods Hole, Massachusetts 02543, USA

\section{G. Miller and J. Black}

Institute of Arctic and Alpine Research, University of Colorado, Boulder, Colorado 80303, USA

[1] The utility of elemental mapping by scanning X-ray fluorescence (XRF) in the study of annual laminated sedimentary records was investigated on eight annually laminated sediment types. The examples were chosen to illustrate the potential of this approach in environments dominated by terrigenous, biological and chemical deposition. Individual laminae were identifiable in elemental maps of all sediment types and were enhanced through the use of data reduction techniques (e.g., principal components transformation). Laminae were least apparent in clastic dominated systems with no seasonal changes in sediment sources. In biologically dominated systems, element maps provided insights into the composition of the varve subcomponents, related to alternating terrigenous and biologically dominated seasonal periods of deposition. Chemically precipitated structures were more prevalent than expected from visual investigations alone and may provide an underutilized paleoenvironmental signature of changing limnological conditions. Elemental mapping offers a valuable tool for the study of laminated records that complements existing techniques (e.g., SEM, digital image analysis).

Components: 8488 words, 3 figures, 1 table.

Keywords: micro-XRF scanner; major elements; varve; lamination. 
Index Terms: 1051 Geochemistry: Sedimentary geochemistry; 1694 Global Change: Instruments and techniques; 4239 Oceanography: General: Limnology $(0458,1845,4942) ; 4215$ Oceanography: General: Climate and interannual variability $(1616,1635,3305,3309,4513)$.

Received 27 August 2007; Revised 17 November 2007; Accepted 14 December 2007; Published 27 February 2008.

Shanahan, T. M., J. T. Overpeck, J. B. Hubeny, J. King, F. S. Hu, K. Hughen, G. Miller, and J. Black (2008), Scanning microX-ray fluorescence elemental mapping: A new tool for the study of laminated sediment records, Geochem. Geophys. Geosyst., 9, Q02016, doi:10.1029/2007GC001800.

\section{Introduction}

[2] Annually laminated (varved) sedimentary records can provide an invaluable source of annual to seasonal-scale paleoenvironmental changes over timescales of hundreds to thousands of years. Understanding the nature of varve formation is crucial for appropriately utilizing finely laminated sediments for both chronological development and extracting paleoenvironmental information. Although the study of modern sedimentation processes through techniques such as sediment traps may provide the most ideal method for understanding how sedimentary structures are formed and preserved [Dean, 2002; Teranes and Bernasconi, 2000; Thunell et al., 1995], it is often logistically and financially impractical to do such modern calibration studies at remote sites. In such cases, it is necessary to develop an understanding of the processes of laminae formation from the sediments themselves.

[3] Growing interest in the development of highresolution records of past climate changes has led to the development of numerous techniques for studying sediment laminations including X-radiography, digital image analysis, and scanning electron microscopy (SEM) [Dean et al., 1999; Francus et al., 2004; Principato, 2004; Schimmelmann and Lange, 1996]. In particular, backscatter electron imagery (BSEI) has become a widely used and valuable technique for studying the sedimentary fabrics associated with varve formation. A number of studies have illustrated the usefulness of this technique in resolving the physical and biological components of the annual cycle of sedimentation [Burke et al., 2002; Dean et al., 1999; Hughen et al., 1996b; Kemp, 2003; Schiefer, 2006; Tiljander et al., 2002].

[4] A complementary approach is elemental mapping by scanning micro-X-ray fluorescence $(\mu-$ XRF) [Böning et al., 2007]. This method allows for the identification of changes in elemental abundances associated with sediment laminations at very high spatial resolution $(20-100 \mu \mathrm{m})$, which can provide insights into interannual and intraannual changes in sediment elemental composition. $\mathrm{X}$-ray maps can also be readily compared to visually identifiable sedimentary structures associated with annual bands to assist in interpreting varve components and the processes leading to their formation. Coupled with down core $\mu$-XRF line scans [Jansen et al., 1998], variations in elemental abundances can also potentially be used for verification of visual varve counts and identification of changes in sedimentation processes [Böning et al., 2007].

[5] This paper examines the use of $\mu$-XRF mapping for the study of laminated sediments. The basic analytical procedures behind $\mu$-XRF analysis of sediment records are described, and a number of examples illustrating the utility of this method are presented. Examples were chosen from a variety of lacustrine and marine settings known to preserve annual sediment laminations via differing physical, biological and geochemical processes.

\section{Methods}

\subsection{Instrumental Setup}

[6] Measurements were made using an EDAX Eagle III tabletop scanning $\mu$-XRF analyzer located in the Geosciences Department at the University of Arizona. This instrument is equipped with an Xray tube with a Mo target that is capable of generating incident $X$ rays with energies of up to $50 \mathrm{KeV}$ and $1-1000 \mathrm{~mA}$. This permits the potential identification of elements from $\mathrm{Na}$ to $\mathrm{U}$ in lowdensity samples. Measurements are made with an energy dispersive $\mathrm{LN}$ cooled $\mathrm{Si}(\mathrm{Li})$ detector with a $10 \mu \mathrm{m} \mathrm{Be}$ window. The Eagle III uses a monolithic polycapillary optical X-ray focusing tube with an effective beam spot of $20 \mu \mathrm{m}$ at the optimal focusing distance. The use of polycapillary focusing optics is critical because it enables the machine 
to achieve very small beam sizes, and consequently small measurement areas, without sacrificing beam intensity and sensitivity. The effective spot size increases moderately for higher-energy $\mathrm{X}$ rays (to about $40 \mu \mathrm{m}$ ) because of the greater penetration depths of the primary $\mathrm{X}$ rays contributing to the fluorescence of heavier elements. Sample location is recorded by two CCD cameras (10x and 100x), which allow for precise location of the X-ray beam on the sample.

\subsection{Preparation of Samples}

[7] Measurements may be made either under vacuum or in air, allowing for analysis of either wet sediment cores with clean surfaces or resin embedded sediment slabs prepared following standard procedures described elsewhere [e.g., Pike and Kemp, 1996]. In our experience, we have found that much better results may be obtained using embedded pucks under vacuum, particularly for high-resolution $(<100 \mu \mathrm{m})$ studies. This is because microscale surficial effects in unprepared sediments, caused by factors such as variable surface roughness and water formation on the sample surface can produce analytical noise through absorption and scattering of $\mathrm{X}$ rays. Furthermore, many of the lighter elements of interest (e.g., Al) are difficult or impossible to measure accurately in air, and are more sensitive to surface and matrix effects due to the low energy of their fluorescing $\mathrm{X}$ rays. Finally, during the long measurement periods (hours) needed for the production of X-ray maps, condensation tends to develop on the surface of the sediment core, potentially posing a problem for even semiquantitative XRF analysis. An advantage of using resin embedded blocks is that a direct comparison can be made between the elemental maps and investigations of thin sections from the same material. We note, however, that direct XRF measurement on thin sections rather then resin blocks is problematic because the depth of the fluorescing $X$ rays $(100-150 \mu \mathrm{m})$ may exceed the sample thickness, resulting in a potentially significant contribution from the underlying glass slide.

\subsection{Scanning $\mu$-XRF Analysis of Sediments}

[8] Traditional, energy-dispersive X-ray fluorescence (XRF) analysis is a very common analytical tool for the accurate and quantitative determination of major and trace element concentrations in a wide variety of materials. It has an advantage over other techniques in that it requires relatively little sample preparation, provides moderately rapid measurement times and can measure a wide range of elements ( $\mathrm{Na}$ to $\mathrm{U})$ simultaneously, as well as over a wide range of concentrations.

[9] Energy-dispersive XRF analysis is typically performed by exciting a sample with a well-characterized, primary X-ray source (e.g., Rhodium, Molybdenium). This results in the emission (fluorescence) of secondary $X$ rays with energies that are characteristic of the elements in the sample. Elemental concentrations can then be determined from the intensities (count rates) of the $\mathrm{X}$ rays at each energy level. Quantification is performed using known standards, or by theoretical calculations (e.g., the method of fundamental parameters) or some combination of the two [Jenkins et al., 1995].

[10] Quantitative analysis by XRF requires strict sample preparation guidelines. The two most accepted approaches for XRF sample preparation are the fused bead and the pressed pellet techniques [e.g., Blank and Eksperiandova, 1998; Jenkins et al., 1995]. Both approaches attempt to minimize the effects of sample inhomogeneities, packing and particle size effects, all of which may produce significant errors in quantitative XRF results. Over the last several years, a number of studies have employed in situ $\mu$-XRF scanning techniques to the development of long, continuous paleoenvironmental records by in situ line-scan analysis of sediment cores [e.g., Haug et al., 2001; Peterson et al., 2000; Rohl et al., 2000]. In this approach, temporal patterns of elemental variations are produced by scanning the length of wet sediment cores directly. While this technique lacks the accuracy of more conventional quantitative approaches, it offers the potential for rapid, high-resolution results without the need for high-resolution sampling and time-consuming sample preparation.

[11] Recently, a number of studies have also begun to explore the potential of scanning XRF technology for mapping of biological and geological materials, in order to understand the spatial, as well as the temporal variations in the elemental composition of geological materials [Civici, 1997; Fukumoto et al., 1999; Vekemans et al., 1999; Böning et al., 2007]. The primary limitation to the XRF mapping approach is the time required to produce the map. In comparison with a simple onedimensional line scan, the number of locations in a map (and therefore the time) increases exponentially. Typical measurement times for quantitative sediment line scans are approximately $30-60$ s per 
location. Depending on the length of the scan and the measurement beam spot size $(0.02-1.0 \mathrm{~mm})$, producing detailed quantitative maps of sediments may therefore be prohibitively time-consuming. However, semiquantitative maps are possible when measurements are made rapidly (approximately $2-$ $5 \mathrm{~s}$ per location) by taking advantage of the autocorrelation of concentrations at closely spaced locations. Further decreases in mapping time may be made by increasing the distance between measurements, taking into account the size of the sedimentary structures of interest.

[12] In the current study, resin-embedded slabbed samples were typically measured at $500 \mathrm{KeV}$ and $1000 \mathrm{~mA}$ under vacuum to optimize analysis for the elements of interest ( $\mathrm{Al}-\mathrm{Mn})$. Unfortunately, concentrations of sulfur were not obtained because of problems with overlapping signals between the Mo X-ray source and S. The X-ray beam was maintained at a diameter of $20 \mu \mathrm{m}$, and X-ray counts were integrated over measurement times of $5 \mathrm{~s}$ per spot. To maximize efficiency and minimize measurement times, we varied the number of discrete measurements per unit area, depending on the size of the mapping area and the dimensions of the sedimentary structures. Typically, the distance between individual measurements was approximately $100 \mu \mathrm{m}$. Total analysis times also varied, but typically took between 24 and $48 \mathrm{~h}$ per map.

\subsection{Multidimensional Analysis of XRF Maps}

[13] Although visual examination of XRF sediment maps can provide valuable insights into the geochemical makeup and origin of sedimentary structures, methods which have been previously utilized for simplifying and interpreting multidimensional data sets, such as dimensionality reduction and image segmentation [Bonnet et al., 1997; Vekemans et al., 1999] can improve our understanding of these data sets. These methods can be particularly valuable in noisy data sets like the ones generated here. Because sediment structures such as laminations can be considered to be composed of a series of sequential, quasi-homogeneous phases, in many cases it may also be possible to segment the multidimensional elemental maps into a limited number of phases reflecting discrete periods of deposition [Bonnet et al., 1997].

[14] A number of methods have been developed for identifying the dominant phases from elemental maps in a variety of materials and have shown some success in automating image segmentation [e.g., Bonnet et al., 1997; Vekemans et al., 1999]. In the present study, we apply a procedure similar to that described by Vekemans et al. [1999], in which principal components analysis (PCA) is used to reduce the large arrays of multispectral data into a few primary components explaining the majority of the variation in the data set. Data reduction of multispectral elemental maps into their principal components serves several purposes. First, it increases the efficiency of the analysis by removing redundancy in the data sets. In addition, restricting analysis to those principal components accounting for largest proportion of the variance effectively serves as a noise filter, critical for elemental data produced with short measurement times. Finally, PCA provides a means of understanding the relationships between variability in the different elements in the sample. In the present study, we use a version of PCA that is well suited to the analysis of multispectral two-dimensional images (termed the Principal Component Transformation (PCT), or the Karhunen-Loeve or Hotelling transformation), to derive two-dimensional maps of the PCT loadings, their eigenvalues and eigenvectors [Schowengerdt, 1997].

\section{Laminated Sedimentary Records}

[15] Although a wide variety of sediment varve types have been recognized [e.g., Anthony, 1977; Kelts and Hsu, 1978; Saarnisto et al., 1977; Sturm and Matter, 1978], most can be categorized into three main types, or some combination of these, based on their process of formation: physical, biological and chemical [O'Sullivan, 1983]. To examine the potential usefulness of XRF elemental mapping in the study of laminae formation, we have mapped resin embedded blocks of laminated sediments from a variety of sedimentary systems, encompassing each of these categories (see Table 1). Our examples include two clastic-dominated glacial lake systems (Lake Hvitarvatn, Iceland; and Lake Linnevatnet, Svalbard) and three biological systems, two of which are controlled by seasonal diatom blooms (Soper Lake, Baffin Island; Steel Lake, Minnesota) and a third marine site (Cariaco Basin, Venezuela) which is dominated by seasonal coccolithophorid algae blooms. A third set of examples come from sites with sediments that are known to be composed of a variety of combinations of clastic, biological, and geochemical laminations (Fayetteville Green Lake, New York; 
Table 1. Varve Examples Used in This Study

\begin{tabular}{llll}
\hline \multicolumn{1}{c}{ Site } & \multicolumn{1}{c}{ Location } & \multicolumn{1}{c}{ Varve Type } & \multicolumn{1}{c}{ Contributor } \\
\hline Hvitarvatn & Iceland & clastic & G. Miller, J. Black, INSTAAR \\
Linne & Svalbard & clastic & A. Werner, Mt. Holyoke College \\
Steel Lake & Minnesota & biological (diatomaceous) & F. S. Hu, University of Illinois \\
Soper Lake & Arctic & biological (diatomaceous) & J. T. Overpeck and K. Hughen \\
Cariaco Basin & Venezuela (marine) & biological (foraminifera) & U. Arizona, Woods Hole Oceanographic Inst. \\
Fayetteville Green & New York & chemical (carbonate) & Brad Hubeny and John King, U. Rhode Island \\
Pettaquamscutt & RI (estuary) & $\begin{array}{l}\text { chemical (magnetite, pyrite) } \\
\text { chemical (Fe, Mn minerals) }\end{array}$ & $\begin{array}{l}\text { Brad Hubeny and John King, U. Rhode Island } \\
\text { Lake Bosumtwi }\end{array}$ \\
\hline
\end{tabular}

Pettaquamscutt River basin, Rhode Island, and Lake Bosumtwi, Ghana).

\section{Results and Discussion}

\subsection{Clastic-Dominated Systems}

\subsubsection{Lake Hvitarvatn}

[16] Lake Hvitarvatn is a glacier-dominated lake located in the central highlands of Iceland. It has an area of $29.4 \mathrm{~km}^{2}$ and a maximum depth of $84 \mathrm{~m}$ [Black et al., 2006]. Hvitarvatn is fed primarily by Langjokull, the second largest ice cap in Iceland. One outlet glacier from the glacier calves into the lake, a second withdrew at around 1940. Annual sedimentation rates are high (approximately $1 \mathrm{~cm} \mathrm{a}^{-1}$ ) and consist of a visually distinct clay cap deposited in winter, a mixture of silt and clay in the spring, and coarser, meltwater-derived glacial sands in the summer. Diatoms and authigenic carbonate are scarce or absent in the sediments and organic productivity is low [Black et al., 2006]. Because of the lack of evidence for either biological or geochemical components in the sediments, Lake Hvitarvatn provides a strict end-member case of a clastic-dominated system.

[17] Sediment thin sections from Lake Hvitarvatn clearly show the distinct, alternating coarse-fine sediment progression that makes up the annual cycle of sediment deposition [Black et al., 2006] (Figures 1a-1c). XRF elemental maps show little change in the composition of the laminae, as predicted from the lack of changes in the sediments deposited throughout the year. The lack of a strong annual signal in these results is not improved upon using the PCT technique. However, visual inspection suggests that the coarsest material yield higher intensities for the heavier elements (e.g., Ti, Fe) and lower intensities for the lighter elements (Al, $\mathrm{Si}, \mathrm{Ca}$ ) than the silty-clay laminae. Because the mineralogy does not change, and there is little biological influence on the lake, some other factor must be causing this relationship.

[18] One possibility is that the changes in elemental intensities reflect variations in sediment grain size. There are two ways in which grain size may alter the elemental intensities. The first relates to the packing of sediments, which should be inversely proportional to grain size. More tightly packed sediments should generate greater element intensities because the beam excited more material (and less pore space). Since lighter elements have lower energies and are derived from much shallower sample depths, we would expect them to be most sensitive to this effect. This is consistent with our observation that the finer grained (e.g., more tightly packed) material yields higher element intensities for the lighter elements than the coarser material. An alternative explanation is that the lower XRF intensities associated with coarser grain sizes are caused by sample self-absorption of fluorescing $X$ rays. In large grained samples, where the size of individual grains approaches the X-ray attenuation length for low-energy $\mathrm{X}$ rays, these $\mathrm{X}$ rays will be preferentially underrepresented because they lack sufficient energy to escape from the sample and are reabsorbed. As a consequence, low-energy X-ray intensities will be reduced for the larger grain sizes in comparison with the finer grain sizes. More detailed studies of grain size variations and laminae scale changes in sediment density are required to assess these two possibilities. However, these results suggest that caution should be used in interpreting elemental intensity records from clastic-dominated sediments, especially on a varve scale.

\subsubsection{Lake Linnevatnet}

[19] Lake Linnevatnet is a small $(1 \times 5 \mathrm{~km}$ diameter) glacial-fed lake located at the mouth of Isfjord, Svalbard [Snyder et al., 2000]. Inflow to the lake is provided by spring snowmelt and melting of the Linnevatnet Glacier and several 


\section{Clastic varve examples}

\section{Lake Hvitarvatn, Iceland}

(a) Thin section photograph

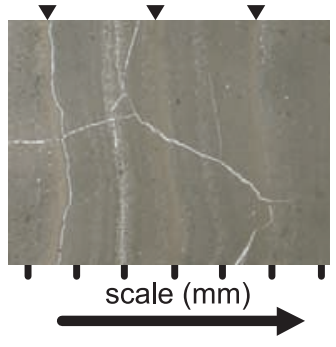

Net Intensity ranges (cps):

Al: 0-123 Ca: 0-3810

Si: 0-510 Fe:11-17510

Ti: 0-3650 (b) XRF elemental maps
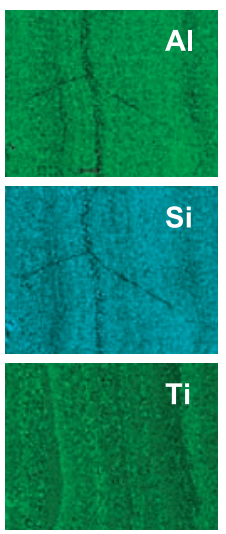

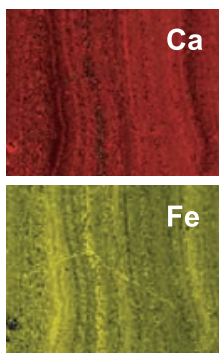

i. (c) Principal component transform



\section{Lake Linne, Svalbard}

(d) Thin section photograph

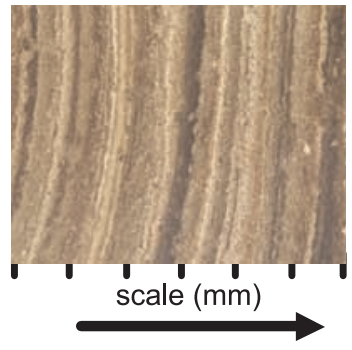

Net Intensity ranges (cps):

Al: 0-26 Ca: 0-800

Si: 0-220 Fe: 0-2320

K: 0-195 (e) XRF elemental maps
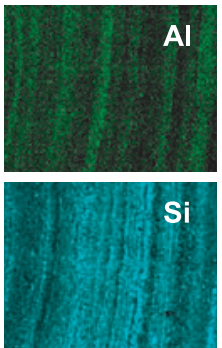

$\mathbf{K}$
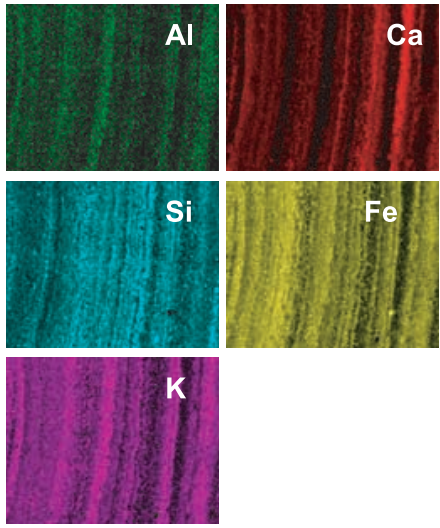

(f) Principal component transform

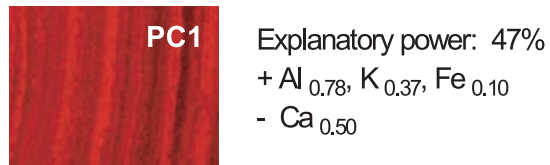

PC2 Explanatory power: $32 \%$

$+\mathrm{Al}_{0.62}, \mathrm{Ca}_{0.54}$

- $\mathrm{Fe}_{0.48}, \mathrm{~K}_{0.31}$

PC3

Explanatory power: $9 \%$

$+\mathrm{Ca}_{0.56}, \mathrm{~K}_{0.73}$

- $\mathrm{Fe}_{0.10}, \mathrm{Si}_{0.37}$

Figure 1. Examples of clastic varves: $(a-c)$ Lake Hvitarvatn and $(d-f)$ Lake Linnevatnet. Figure 1a shows transmitted light thin section photograph of sediment showing distinct sediment laminations. Annual varve boundaries are designated with black triangles. No designations were made on the Lake Linnevatnet photograph because the annual interval of deposition is not well constrained. Figures $1 \mathrm{~b}$ and 1e show XRF elemental intensity maps measured on a resin-embedded sediment slabs. Only the elements with significant intensity variations are shown. Data are plotted as normalized grey-scale intensity that is colorized to make variations in grey scale more visually apparent (lighter indicates higher concentration). Because of inaccuracies as a result of short measurement times, concentrations are reported as intensities (in counts per second) rather than weight \%. The ranges of individual intensities measured for each element within the maps are reported in the bottom left corner. Figures $1 \mathrm{c}$ and $1 \mathrm{f}$ show results of the principle component transformations of the elemental intensity data, plotted in the same manner as the raw XRF data. Also reported are the eigenvalues for the elements with the strongest weightings for each of the PCs (subscripts). 
smaller, cirque glaciers. Sedimentation is primarily glaciofluvial, and originates from the Linne River, which carries sediment-laden glacial meltwater from the Linnevatnet Glacier. Fine sand and silt are delivered to the lake during spring runoff events while summer ablation of the glacier results in the deposition of fine silt and clay laminae. Large summer precipitation events are associated with coarse layers within the finer clay-silt summer laminae. Two distinct lithologic terranes are present in the catchment. Sediments from the first area are composed of quartz, feldspar, muscovite, chlorite and kaolinite whereas the sediments from the second terrane are predominantly dolomitic [Snyder et al., 2000].

[20] On the basis of a comparison between laminae stratigraphy and independent dating methods, each varve is composed of numerous fine laminations, possibly reflecting individual precipitation runoff events (Figures 1d-1f). Although the elemental distributions do not appear to provide any insights into identification of the annual interval of sedimentation, XRF maps suggest that the individual laminae have distinct elemental compositions, and may represent different source regions contributing sediment during different runoff events. This is supported by the PCT analysis, which reveals distinct variations between laminae dominated by calcium (and usually at least one other element) and the aluminosilicate elements. In the absence of evidence for authigenic carbonate production in the lake, we propose that the Ca-rich layers represent intervals of runoff from the dolomite portion of the catchment, whereas the $\mathrm{Al}, \mathrm{K}$ and Fe rich laminae represent runoff from the aluminosilicate-dominated portion of the catchment (PC 1,2). Ongoing work using sediment traps and studies of sediment cores will provide more insights into these processes in the future. Provided the sources of these individual laminae can be separated and identified, and their deposition tied to paleoenvironmental changes within the catchment over the historical period, the XRF mapping results indicate that rapid elemental scanning could be a potential means of identifying individual runoff events, and their sources within the catchment.

\subsection{Biological Systems}

\subsubsection{Steel Lake, Minnesota}

[21] Steel lake fills a kettle hole in the Itasca moraine in north-central Minnesota. The lake is in the chain of lakes (Crystal, Williams, Doe, Mary, Island, Steel, Shingobee) in the Shingobee River watershed [Winter, 1997], and it has a small stream running through it today. Its small surface area $\left(0.23 \mathrm{~km}^{2}\right)$ compared to its depth $(21 \mathrm{~m})$, results in anoxic bottom waters and the preservation of annual sediment laminations [Tian et al., 2005, 2006; Wright et al., 2004]. Annual sedimentation is composed of three laminae: a light-colored laminae of concentrated calcite and diatoms deposited during the growing season, a thin brown lamina of diatoms and iron oxides deposited during autumn overturning, and a dark, organic rich layer deposited in winter (Figures 2a-2c). The two darker layers are usually visually indistinguishable without microscopic assistance [Tian et al., 2005]. The latest Holocene sediments used for elemental mapping in this study contain only a small amount of clastic material; over $80 \%$ of the material is composed of biogenic silica, endogenic carbonate and organic matter. The existing detrital mineral fraction is composed primarily of quartz and feldspars [Tian et al., 2005, 2006; Wright et al., 2004].

[22] In contrast to the purely clastic varved systems described above, the XRF elemental maps provide more insight into the complex sequence of annual sedimentation at Steel Lake (Figures 2a-2c). The dominant elemental signature making up the varves is alternating bands of $\mathrm{Ca}$ and bands of $\mathrm{Fe}$ and $\mathrm{Si}$ (PC1). The $\mathrm{Ca}$ is most likely derived from endogenic calcite [Tian et al., 2006] that formed as a result of algal $\mathrm{CO}_{2}$ uptake for photosynthesis during the spring and early summer. Si reflects enhanced diatom productivity during seasonal overturn, as suggested by its co-occurrence with $\mathrm{Fe}$. Because the detrital mineral fraction should not contain $\mathrm{Fe}$, the most likely source of this $\mathrm{Fe}$ is $\mathrm{Fe}$ oxides and oxyhydroxides formed when Fe-rich, anoxic bottom waters are mixed up into the oxygenrich epilimnion. This interpretation is consistent with the previous suggestion that authigenically precipitated $\mathrm{Fe}$-oxides are a significant constituent of the annual laminae [Tian et al., 2005].

[23] Close inspection of the elemental plots indicates that in each varve, two thin layers of $\mathrm{K}$ and $\mathrm{Al}$ (PC2) occur in the intervals between the $\mathrm{Ca}$ laminae and the Si-Fe laminae. The most likely source of $\mathrm{K}$ and $\mathrm{Al}$ is mineral particles from watershed soil erosion and/or eolian activity. The first thin band probably represents inputs of terrigenous clastic material in the early to midsummer, when nutrients are depleted and aquatic productivity is low. The second annual band following the summer peak in diatom productivity probably represents detrital deposition during the winter, 


\section{Biological varve examples}

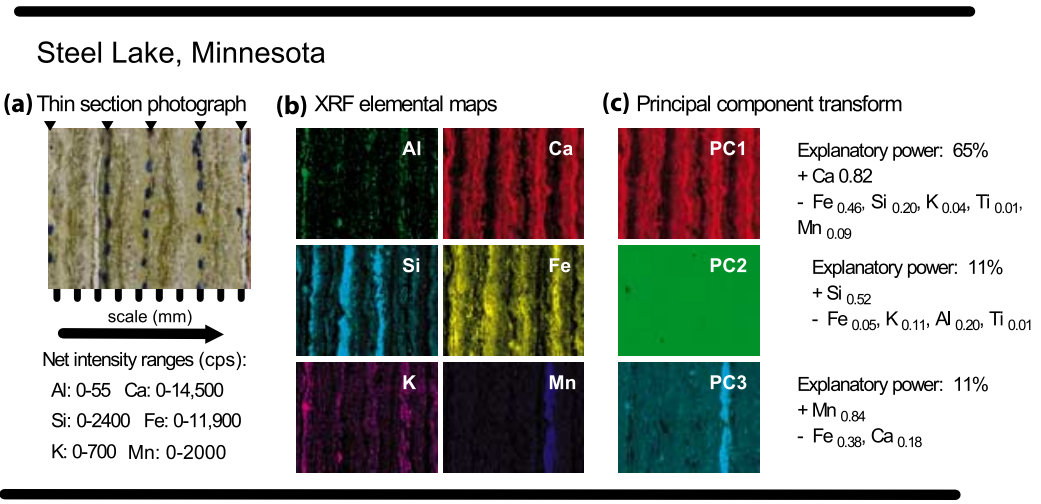

Soper Lake, Canadian Arctic

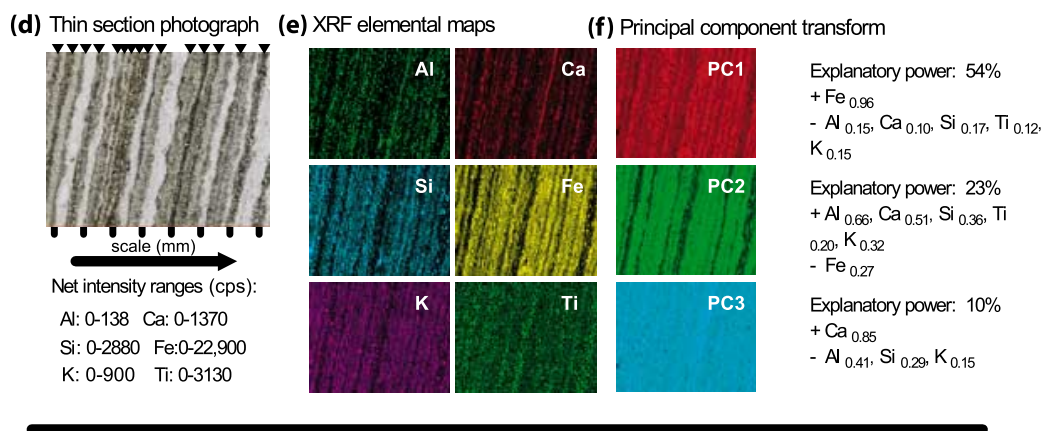

Cariaco Basin, Venezuela

(g) Thin section photograph (h) XRF elemental maps
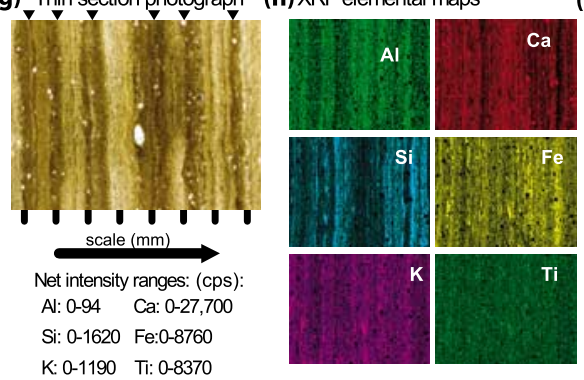

(i) Principal component transform

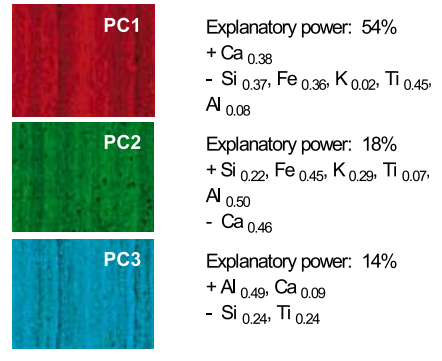

Figure 2. Same as Figure 1 except for biogenic varve examples: $(a-c)$ Steel Lake, $(d-f)$ Soper Lake, and $(g-i)$ Cariaco Basin. In the Steel Lake thin section photograph, the blue dots were manually added to the thin section to mark the varve boundaries.

also when productivity is also reduced. There is no reason to expect increases in soil erosion or eolian dust deposition during these seasons. Thus the elevated concentrations of the mineral fraction in these intervals likely reflect reduced dilution from endogenic calcite and $\mathrm{Fe}$ oxides.

[24] PC3 is dominated by the distinct band of Mn that is present in only one of the varves investigated in this study. Like Fe, $\mathrm{Mn}$ is a redox-sensitive metal and its presence is probably an indicator of changing redox potential in the water column and sediment-water interface. Unlike Fe-oxides, which are present in every varve, Mn-oxides occur less regularly. $\mathrm{Fe}$ is much more common than $\mathrm{Mn}$ in lakes, which could account in part for its more dominant role in the sediment record. Differences in preservation may also explain the more regular occurrence of Fe-oxides in comparison to the $\mathrm{Mn}$ oxides in the sediments. Previous authors have suggested that the preservation of Fe precipitates is enhanced by the formation of ferric hydroxide colloids or gels, which are more stable under reducing conditions than Mn-oxides [Dean, 2002; Stauffer and Armstrong, 1986; Tipping et al., 1981]. Alternatively, the differences in preservation 
may be related to changes in the redox potential of bottom waters and sediments. Specifically, the Mnlaminae may have formed during a year with stronger or longer-lasting oxidation of bottom waters, as a result of either enhanced lake overturning, or reduced production of organic matter and thus reduced consumption of oxygen in bottom waters. These processes may also have increased the redox potential of surface sediments and enhanced the preservation of Mn oxides. Although additional studies are needed to understand the processes controlling the deposition and preservation of redox metals in laminated basins, the data presented here suggest that the scanning XRF approach may be valuable in identifying the frequency of these events for targeted geochemical analysis and potentially, for reconstructing paleoredox conditions.

\subsubsection{Soper Lake, Canadian Arctic}

[25] Soper Lake is located on southern Baffin Island within the tidal zone of the Hudson Strait. It has a surface area of $0.8 \mathrm{~km}^{3}$, a maximum depth of $30 \mathrm{~m}$ and obtains freshwater inputs from several streams in its catchment [Hughen et al., 2000]. It is separated from the Hudson Strait by an emergent sill, which is flooded during high tides with dense saline water. The density differences between the fresh and saline waters in the lake induce stratification and promote bottom water anoxia. Annual sediment couplets are composed of alternating dark and light layers (Figures 2d-2f). Dark layers are composed primarily of silt and clay particles derived from snowmelt runoff in the spring and early summer whereas lighter layers are rich in diatoms deposited during periods of high productivity [Hughen et al., 2000].

[26] Elemental maps of thin sections from Soper Lake reveal high concentrations of Fe. Positive loadings for $\mathrm{Fe}$ and negative loadings for the other major elements ( $\mathrm{Al}, \mathrm{Si}, \mathrm{Ca}, \mathrm{Ti}, \mathrm{K})$ (and the opposite relationship for $\mathrm{PC} 2$ ) suggest that the $\mathrm{Fe}$ is contained in a geochemically precipitated phase, such as pyrite. In modern euxinic water bodies, pyrite can form in either the water column or diagenetically in the sediments [Suits and Wilkin, 1998; Wilkin and Barnes, 1997a]. The abundance of the Fe-phases in annual laminations is consistent with either possibility and additional geochemical and water column studies are needed to address the mechanisms behind pyrite formation.

[27] Interestingly, the elemental maps from Soper lake do not show a Si-dominated phase, which we expected on the basis of reported seasonal diatom productivity. Instead, PC3 is associated with distinct $\mathrm{Ca}$ layers, which we attribute to the deposition of authigenic calcium carbonate as a result of $\mathrm{CO}_{2}$ drawdown in the mixed layer during high-productivity periods. The lack of a diatom Si signal may be the result of high terrigenous Si inputs, which make it difficult to resolve the seasonal cycle of $\mathrm{Si}$ deposition from the XRF map data. Unfortunately, this finding highlights a significant limitation of the XRF scanning technique, which can resolve differences in elemental compositions but not the form (e.g., biological $\mathrm{Si}$, aluminosilicate minerals) in which those elements are deposited.

\subsubsection{Cariaco Basin, Coastal Venezuela}

[28] The Cariaco Basin is a deep (up $1400 \mathrm{~m}$ ), anoxic marine basin located off the coast of Venezuela [Peterson et al., 1991]. A shallow sill isolates the deep water from the rest of the ocean, minimizing deepwater mixing and transport of oxygen to bottom waters. Annual laminations in the Cariaco Basin are composed of a light, coccolith-rich carbonate layer (and a second diatom lamina in portions of the record) formed during the winter-spring when upwelling and productivity are at their highest, and a dark terrigenous layer formed during the summer-fall, when rainfall is highest over northern South America [Haug et al., 2001; Hughen et al., 1996a]. Previous work using scanning XRF techniques to develop long, highresolution records of past terrigenous input have provided some of the most valuable records of hydrologic changes in South America, to date [Haug et al., 2001, 2003; Peterson et al., 2000]. These studies showed, convincingly, that the light layers are composed primarily of $\mathrm{Ca}$ (in carbonate) and the dark layers contain significant amounts of $\mathrm{Fe}$ and Ti. On the basis of the similarities in the depth profiles of these two elements, they argued that neither was diagenetically altered.

[29] XRF elemental maps support previous work. Not surprisingly, the dominant component in the sediments is $\mathrm{Ca}$, which is derived from the calcium carbonate coccoliths of haptophyte algae deposited during periods of high productivity (Figures $2 \mathrm{~g}-$ 2i). The annual light-dark alternating layers in the thin section photograph are most visible in the intensities of the major siliciclastic elements (especially $\mathrm{Al}$, and $\mathrm{K}$ ) and $\mathrm{PC} 1$. Finer-scale variations in elements such as $\mathrm{Si}$ and $\mathrm{Fe}$ indicate that annual layers are composed of numerous individual layers, possibly representative of individual storm events. Over the interval mapped here, these layers show 
both changes in concentration and in frequency. This suggests that variations in siliciclastic elements in Cariaco Basin sediments are a function of both the intensity and the frequency of runoffgenerating storms. The absence of a Ti signal shows the difficulty in obtaining accurate maps using short measurement times when elemental concentrations are low. This problem is more acute for marine sediments, which have lower concentrations of terrigenous materials in comparison with lacustrine sediments.

\subsection{Chemical-Biological Systems}

\subsubsection{Fayetteville Green Lake, New York}

[30] Fayetteville Green Lake (FGL) is a small $\left(0.3 \mathrm{~km}^{2}\right.$ area $)$, deep $(52 \mathrm{~m})$ meromictic lake located approximately $15 \mathrm{~km}$ east of Syracuse, New York. The lake is believed to have originated as a glacial meltwater plunge-pool basin [Hilfinger et al., 2001]. Permanent stratification is maintained by a salinity-induced chemocline at $18 \mathrm{~m}$ water depth, which allows for the preservation of annual varves [Hilfinger et al., 2001; Ludlam, 1981, 1984]. The salinity and chemical differences between surface and deep waters are caused primarily by the discharge of $\mathrm{Ca}^{2+}$ and $\mathrm{SO}_{4}^{2-}$ rich groundwaters into the lake from the gypsum bearing Silurian Vernon Shale. Sediments deposited in the basin consist of light-dark annual laminae couplets. The pale, calcite rich laminae are chemically precipitated in association with photosynthetic blooms of the cyanobacterial picoplankton Synechococcus in the summer [Hilfinger et al., 2001]. Darker laminations reflect organic- and terrigenous-rich deposition in the winter. The postdepositional formation of diagenetic pyrite in the sediments of FGL has also been reported [Suits and Wilkin, 1998].

[31] The elemental maps from FGL are similar to those from Cariaco, with most of the material in the sediments containing $\mathrm{Ca}$ in the form of calcium carbonate, consistent with previous observations (Figures 3a-3c). Interestingly, despite the changes in color and texture of the lighter portion of the varve couplets, XRF mapping suggests that this material is also nearly entirely composed of carbonate. This observation is supported by the PCT, which shows that the first component (PC1) is dominated by $\mathrm{Ca}$. The thin dark layers also contain significant amounts of terrigenous material, as evidenced by the clear bands of $\mathrm{Si}, \mathrm{Al}, \mathrm{Fe}$ and $\mathrm{Ti}$ (PC2). These bands are relatively restricted spatially in comparison to the carbonate layers, suggest- ing their deposition is confined to a single season or depositional period. It is likely that this is the late spring and early summer period of snowmelt, when large quantities of terrigenous material may be washed into the basin. Additional comparisons between elemental variations and climate are needed to more fully evaluate these relationships. The XRF maps do not show any indications of widespread formation of diagenetic pyrite as suggested by Suits and Wilkin [1998]. Either the total quantity of diagenetic pyrite formed in the sediments small, or it does not involve any translocation in the sediments that might be visible in elemental maps.

\subsubsection{Pettaquamscutt River Basin, Rhode Island, USA}

[32] The Pettaquamscutt River is a $9.7 \mathrm{~km}$ long estuary, located in southern Rhode Island, USA, which drains into Naragansett Bay. The primary perennial freshwater source to the site is the Gilbert Stewart stream. Stable water stratification is produced locally in deep bottom waters by density differences between the less saline stream waters of the Gilbert Stewart and the brackish tidal waters of the Naragansett Bay [Lima et al., 2005]. These conditions result in permanently anoxic conditions, preventing bioturbation and allowing for the preservation of annually laminated sediment structures.

[33] Annual sediment laminations are composed of a dark colored organic layer produced during the summer when organic biomass from photosynthetic anoxic bacteria is the dominant sedimentary component [Sieburth and Donaghay, 1993] and a light terrigenous layer deposited by runoff to the basin during heavy winter rains [Hubeny, 2006]. Pyrite formation in both the water column (syngenetic) and the sediments of the Pettaquamscutt estuary have been reported by previous workers [Wilkin and Barnes, 1997b]. There is also evidence for the formation of magnetite by photosynthetic anoxic bacteria that reside at the chemocline [Bazylinski et al., 1995]. Mass die-offs of these bacteria during periods of intensified overturning may contribute significantly to the flux of $\mathrm{Fe}$ to the sediments in some years [Bazylinski et al., 1995].

[34] Elemental maps show that the laminae are composed predominantly of $\mathrm{Al}, \mathrm{Ti}, \mathrm{K}$ and $\mathrm{Ca}$, alternating with bands of Fe-rich sediments. As expected from previous work on the mechanisms of varve formation at this site, these correspond to the lighter colored terrigenous and the darkercolored pyrite-rich intervals of deposition, respectively. These differences in the elemental makeup 


\section{Biological-chemical varve examples}

Fayetteville Green Lake ,New York

(a) Thin section photograph

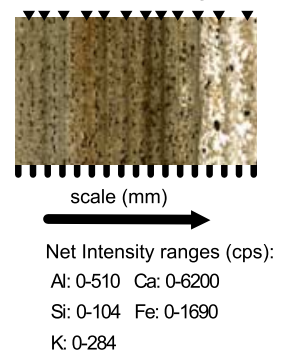

(b) XRF elemental maps

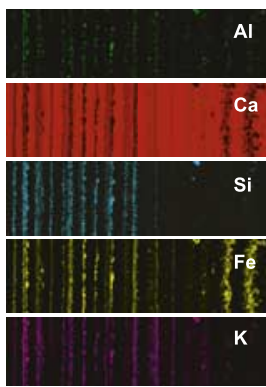

(c) Principal component transform



PettaquamscuttRiver estuary, Rhode Island

(d) Thin section photograph

(e) XRF elemental maps

(f) Principal component transform
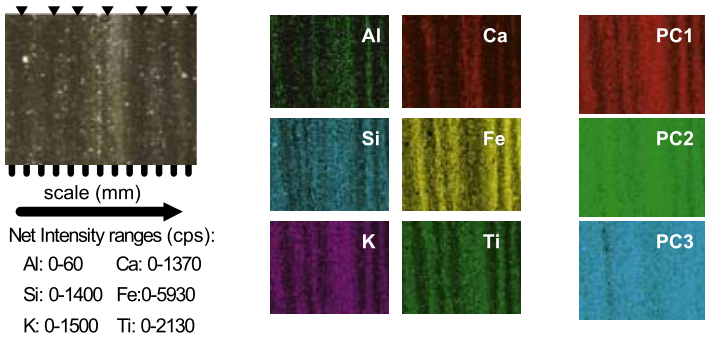

Explanatory power: $32 \%$

$+\mathrm{Al}_{0.22}, \mathrm{Ca}_{0.39}, \mathrm{Si}_{0.53}, \mathrm{Ti}_{0.23}$

$\begin{aligned} & \mathrm{K}_{0.55} \\ - & \mathrm{Fe}_{0.26}\end{aligned}$

Explanatory power: $20 \%$

$+\mathrm{Ca}_{0.30}, \mathrm{~K}_{0.13}, \mathrm{Ti}_{0.31}$

$-\mathrm{Al}_{0.01}, \mathrm{Si}_{0.14}, \mathrm{Fe}_{0.13}$

Explanatory power: $12 \%$

$+\mathrm{Si}_{0.55}$

- $\mathrm{K}_{0.26}, \mathrm{Ti}_{0.17}, \mathrm{Ca}_{0.34}$

Lake Bosumtwi, Ghana xRF elemental maps

(g) Thin section photograph

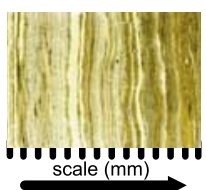

(h)
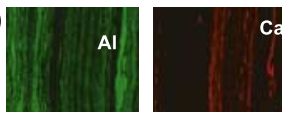

(i) Principal component transform
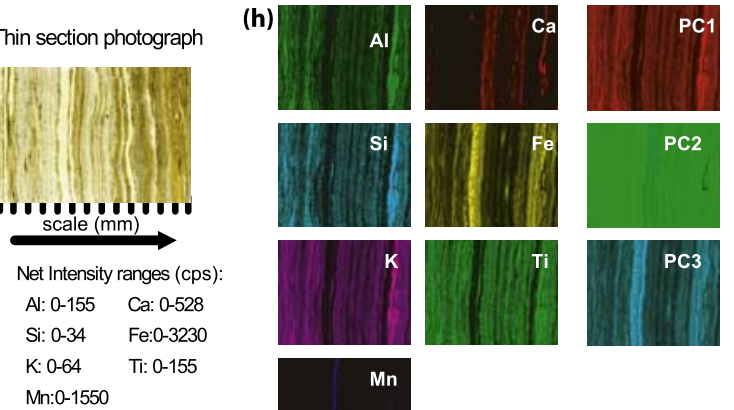

Explanatory power: $48 \%$

$+\mathrm{Al}_{0.47}, \mathrm{Si}_{0.56}, \mathrm{~K}_{0.65}$

- $\mathrm{Ca}_{0.07}, \mathrm{Mn}_{0.06}, \mathrm{Fe}_{0.09}$

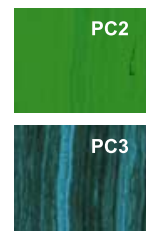

Explanatory power: $16 \%$

$+\mathrm{Fe}_{0.77}, \mathrm{Mn}_{0.28}$

- $\mathrm{Ca}_{0.42}, \mathrm{~K}_{0.32}$
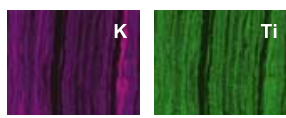

Explanatory power: $11.5 \%$

$+\mathrm{Fe}_{0.18}, \mathrm{Si}_{0.20}, \mathrm{~K}_{0.32}$

- $\mathrm{Ca}_{0.42}, \mathrm{Mn}_{0.28}$

$\mathrm{Mn}: 0-1550$

Figure 3. Same as Figure 1 except for combined clastic-biogenic-chemical varve examples. $(\mathrm{a}-\mathrm{c})$ FayettevilleGreen Lake, $(\mathrm{d}-\mathrm{f})$ Pettaquamscutt River Basin, and $(\mathrm{g}-\mathrm{i})$ Lake Bosumtwi. No varve designations are made on the Lake Bosumtwi thin section photograph because the annual intervals of deposition are too small to mark clearly. The average varve thickness in this section of the sediment record is approximately $150 \mu \mathrm{m}$.

of the laminae are also apparent in PC1, which has strong positive loadings for the terrigenous elements, and negative loadings for Fe. However, PC2 and PC3 do not show any clear association with the proposed depositional mechanisms for this site. Thus the elemental data show no evidence for $\mathrm{Fe}$ concentrations varying independently of the variations in the other elemental constituents. This may indicate that the most important control on Fe concentrations is changes in the input of terrige- nous matter to the system (which dilutes concentrations of Fe-bearing minerals) rather than changes in the production of pyrite and magnetite. The hypothesis that the system is controlled by changes in terrigenous flux via runoff, rather than interannual changes in authigenic production of Fe-bearing minerals from the water column is supported by statistically significant correlations between winter and spring precipitation and light laminae thickness [Hubeny, 2006]. 


\subsubsection{Lake Bosumtwi, Ghana}

[35] Lake Bosumtwi is a small (8 $\mathrm{km}$ diameter), deep $(80 \mathrm{~m})$ tropical lake occupying a meteorite impact crater in tropical West Africa. A steep temperature profile in the upper part of the water column inhibits overturning and maintains anoxic conditions below $10-15 \mathrm{~m}$, throughout the year, though dramatic overturning events, resulting in massive fish kills are reported to occur episodically [Talbot et al., 1984]. Annual sediment couplets are made up of a lighter colored, clastic rich layer deposited during the most intense of the spring and early summer monsoon rainfall period, and a darker organic rich layer deposited during the late summer and early fall [Shanahan et al., 2008]. Sediments also typically contain at least a few percent carbonate formed during the period of high productivity, though no distinct carbonate layer is easily identifiable. In some portions of the sedimentary record, distinct orange-red bands are observed that are presumed to be geochemically precipitated during episodic overturning events.

[36] XRF maps support the hypothesis that the annual laminae at Lake Bosumtwi are composed of a single layer enriched in siliciclastic elements (e.g., $\mathrm{Fe}, \mathrm{Si}, \mathrm{Al}, \mathrm{Ti}, \mathrm{K}$ ) which are deposited during the rainy season (dark laminae) and a lighter laminae composed primarily of organic matter deposited during the productive season. The elemental data indicates that the biogenic layer contains significant amounts of $\mathrm{Ca}$, which we attribute to authigenic $\mathrm{CaCO}_{3}$ precipitated from the water column during periods of high productivity. The highest concentrations of siliciclastic elements in the maps are confined to a turbidite layer (right hand side of the maps). Distinct bands of both Fe and $\mathrm{Mn}$ are also present, and are interpreted here as indicating the occurrence of episodic overturning events, which resulted in the chemical precipitation of these elements. During one of the largest of these events, discrete fine-grained Fe-bearing particles are evident and may be framboides of pyrite. However, XRD analysis indicates that pyrite is overall not a common constituent in the sediments and, for the most part, the $\mathrm{Fe}$ and $\mathrm{Mn}$ are present in other mineral phases, including vivianite $(\mathrm{Mn}, \mathrm{Fe}$ phosphate) and manganosiderite (Mn, Fe carbonate).

[37] Principal components analysis indicates that the elemental variations are dominated by the seasonal deposition of terrigenous material, as seen primarily through $\mathrm{Al}, \mathrm{K}, \mathrm{Si}$ and Ti. Negative loadings for the redox sensitive metals (Fe, Mn) and $\mathrm{Ca}$ indicate that these elements are not depos- ited at the same time as maximum runoff. Mn and $\mathrm{Fe}$ are most likely deposited during the late summer, when temperatures are cooler and wind is at its maximum, decreasing lake stability and allowing overturning to occur. Our observations suggest that $\mathrm{Ca}$ is likely deposited immediately afterward in fall, when productivity is at a maximum. This mechanism may explain the opposite loadings for the redox metals and $\mathrm{Ca}$ in $\mathrm{PC} 2$. These results suggest that down core changes in $\mathrm{Ti}, \mathrm{Si}$ and $\mathrm{Al}$ should provide good proxies for summer monsoon runoff from the catchment, whereas $\mathrm{Ca}$ may indicate variations in lake productivity and $\mathrm{Fe}$ and $\mathrm{Mn}$ should be useful in reconstructing long-term changes in lake stability and overturning events.

\section{Conclusions}

[38] In situ $\mu$-XRF mapping provides a valuable new tool for the analysis and interpretation of finescale sedimentary structures in laminated sedimentary archives, which complements existing approaches such as scanning electron microscopy. In varved sediment records, sublaminae elemental variations can be related to seasonal changes in biology, geochemistry or sedimentary fluxes, providing insights into the nature of sedimentation processes. Furthermore, studies based on visual methods alone may not completely characterize the varve components, and can be significantly enhanced through complementary in situ geochemical techniques like the one presented here. For example, at some sites, elemental mapping demonstrates that $\mathrm{Ca}$ is deposited during discrete time intervals as thin sublaminae, separate from the other major elements, consistent with the seasonal deposition of carbonate from the water column. In other cases, the $\mathrm{Ca}$ is dispersed throughout the sediments, or occurs in association with the other major elements, indicting either the presence of $\mathrm{Ca}$ bearing minerals in the catchment or the formation of diagenetic carbonates in the sediments. In addition, elemental mapping provides information on spatial variations in trace elements, which may not be visually distinct, but which are important for understanding changes in lake stability and redox conditions.

[39] Other sedimentary processes may be more difficult to distinguish from the elemental mapping approach. For example, where there is little seasonal change in the source of the lacustrine sediments, the elemental contrast between laminae is small and elemental mapping has limited utility in identifying or describing the laminae. The elemen- 
tal approach also has difficulties in quantitatively separating biogenic silica from the mineral component, even when statistical methods such as principal component transformations are used. However, it does appear able to confirm that both sources of $\mathrm{Si}$ are important sedimentary components in at least some situations.

[40] Unlike rapid elemental line-scanning approaches, which can rapidly produce long, continuous records of elemental variations in sediment records, the mapping approach provides additional spatial data that helps to better characterize the within laminae variations in elemental composition. Such data is most important in characterizing small-scale sedimentary features important for understanding laminae formation. Our elemental maps suggest that some of these smaller-scale features may show significant variations along laminae, and thus may not be well represented by single line scans. Although the acquisition rate of elemental maps is relatively rapid in comparison with other methods of geochemical analysis that require sediment subsampling, the production of large-scale maps using this method is currently too slow for entire sediment cores. However, such maps may assist in the interpretation of subannual resolution elemental variations observed in $\mu$-XRF line scans of sediment cores and with data produced by visual microscopy and SEM. Thus elemental mapping provides a valuable, complementary paleoenvironmental tool for varve-based analysis.

\section{Acknowledgments}

[41] This work is based on collaborations and discussions developed during an NSF-sponsored workshop on quantitative varve analysis held at the University of Arizona in May 2006. Funding was provided through NSF Earth System History grants and an NSF Instrumentation grant awarded to J.T.O.

\section{References}

Anthony, R. S. (1977), Iron-rich rhythmically-laminated sediments in Lake of the Clouds, Minnesota, Limnol. Oceanogr., 22, 45-54

Bazylinski, D. A., R. B. Frankel, B. R. Heywood, S. Mann, J. W. King, P. L. Donaghay, and A. K. Hanson (1995), Controlled biomineralization of magnetite $\left(\mathrm{Fe}_{3} \mathrm{O}_{4}\right)$ and greigite $\left(\mathrm{Fe}_{3} \mathrm{~S}_{4}\right)$ in a magnetotactic bacterium, Appl. Environ. Microbiol., 61, 3232-3239.

Black, J. L., G. H. Miller, and A. Geirsdottir (2006), Diatoms as proxies for a fluctuating Holocene ice cap margin in Hvitarvatn, Iceland, Eos Trans. $A G U, 87(52)$, Fall Meet. Suppl., Abstract PP41C-08.

Blank, A. B., and L. P. Eksperiandova (1998), Specimen preparation in X-ray fluorescence analysis of materials and natural objects, X Ray Spectrom., 27, 147-160.
Böning, P., E. Bard, and J. Rose (2007), Toward direct, micron-scale XRF elemental maps and quantitative profiles of wet marine sediments, Geochem. Geophys. Geosyst., 8, Q05004, doi:10.1029/2006GC001480.

Bonnet, N., M. Herbin, and P. Vautrot (1997), Multivariate image analysis and segmentation in microanalysis, Scanning Microsc., 11, 1-21.

Burke, I. T., I. Grigorov, and A. E. S. Kemp (2002), Microfabric study of diatomaceous and lithogenic deposition in laminated sediments from the Gotland Deep, Baltic Sea, Mar: Geol., 183, 89-105.

Civici, N. R. V. G. (1997), Energy-dispersive X-ray fluorescence analysis in geochemical mapping, X Ray Spectrom., $26,147-152$.

Dean, J. M., A. E. S. Kemp, D. Bull, J. Pike, G. Patterson, and B. Zolitschka (1999), Taking varves to bits: Scanning electron microscopy in the study of laminated sediments and varves, J. Paleolimnol., 22, 121-136.

Dean, W. (2002), A 1500-year record of climatic and environmental change in Elk Lake, Clearwater County, MinnesotaII: Geochemistry, mineralogy, and stableisotopes, J. Paleolimnol., 27, 301-319.

Francus, P., R. S. Bradley, and J. Thurow (2004), An introduction to image analysis, sediments and paleoenvironments, in Image Analysis, Sediments and Paleoenvironments, edited by P. Francus, pp. 1-7, Springer, Dordrecht, Netherlands.

Fukumoto, N., Y. Kobayashi, M. Kurahashi, and I. Kojima (1999), X-ray fluorescent spectroscopy with a focused X-ray beam collimated by a glass capillary guide tube and element mapping of biological samples, Spectrochim. Acta, Part B, At. Spectrosc., 54, 91-98.

Haug, G. H., K. A. Hughen, D. M. Sigman, L. C. Peterson, and U. Rohl (2001), Southward migration of the intertropical convergence zone through the Holocene, Science, 293, 1304-1308.

Haug, G. H., D. Gunther, L. C. Peterson, D. M. Sigman, K. A. Hughen, and B. Aeschlimann (2003), Climate and the collapse of Maya civilization, Science, 299, 1731-1735.

Hilfinger, I. M. F., H. T. Mullins, A. Burnett, and M. E. Kirby (2001), A 2500 year sediment record from Fayetteville Green Lake, New York: Evidence for anthropogenic impacts and historic isotope shift, J. Paleolimnol., 26, 293-305.

Hubeny, J. B. (2006), Late Holocene climate variability as preserved in high-resolution estuarine and lacustrine sediment archives, Ph.D. thesis, 257 pp., Univ. of R. I., Narragansett.

Hughen, K. A., J. T. Overpeck, L. C. Peterson, and S. Trumbore (1996a), Rapid climate changes in the tropical Atlantic during the last deglaciation, Nature, 380, 51-54.

Hughen, K. A., J. T. Overpeck, R. F. Anderson, and K. M. Williams (1996b), The potential for paleoclimate records from varved Arctic lake sediments: Baffin Island, Eastern Canadian Arctic, in Palaeoclimatology and Palaeoceanography From Laminated Sediments, edited by A. E. S. Kemp, Geol. Soc. Spec. Publ., 116, 57-71.

Hughen, K. A., J. T. Overpeck, and R. F. Anderson (2000), Recent warming in a 5000-year palaeotemperature record from varved sediments, Upper Soper Lake, Baffin Island, Canada, Holocene, 10, 9-19.

Jansen, J. H. F., S. J. Van der Gaast, B. Koster, and A. J. Vaars (1998), CORTEX, a shipboard XRF-scanner for element analyses in split sediment cores, Mar. Geol., 151, 143-153.

Jenkins, R., R. W. Gould, and D. Gedcke (1995), Quantitative $X$-Ray Spectrometry, 484 pp., Marcel Dekker, New York.

Kelts, K., and K. Hsu (1978), Freshwater carbonate sedimentation, in Lakes: Chemistry, Geology, Physics, edited by A. Lerman, pp. 295-324, Springer, New York. 
Kemp, A. E. S. (2003), Evidence for abrupt climate changes in annually laminated marine sediments, Philos. Trans. R. Soc. London, Ser. A, 361, 1851-1870.

Lima, A. L., J. B. Hubeny, C. M. Reddy, J. W. King, K. A. Hughen, and T. I. Eglinton (2005), High-resolution historical records from Pettaquamscutt River basin sediments: 1 . Pb210 and varve chronologies validate record of Cs-137 released by the Chernobyl accident, Geochim. Cosmochim. Acta, 69, 1803-1812.

Ludlam, S. D. (1981), Sedimentation rates in Fayetteville Green Lake, New York, USA, Sedimentology, 28, 85-96.

Ludlam, S. D. (1984), Fayetteville Green Lake, New York, USA. Varve chronology and sediment focusing, Chem. Geol., 44, 85-100.

O'Sullivan, P. E. (1983), Annually-laminated lake sediments and the study of quaternary environmental changes-A review, Quat. Sci. Rev., 1, 245-313.

Peterson, L. C., J. T. Overpeck, N. G. Kipp, and J. Imbrie (1991), A high-resolution late Quaternary upwelling record from the anoxic Cariac Basin, Venezuela, Paleoceanography, 6, 99-119.

Peterson, L. C., G. H. Haug, K. A. Hughen, and U. Rohl (2000), Rapid changes in the hydrologic cycle of the tropical Atlantic during the last glacial, Science, 290, 1947-1951.

Pike, J., and A. E. S. Kemp (1996), Preparation and analysis techniques for studies of laminated sediments, in Palaeoclimatology and Palaeoceanography From Laminated Sediments, edited by A. E. S. Kemp, Geol. Soc. Spec. Publ., 116, 37-48.

Principato, S. M. (2004), X-ray radiographs of sediment cores: a guide to analyzing diamicton, in Image Analysis, Sediments and Paleoenvironments, edited by P. Francus, pp. 165-185, Springer, Dordrecht, Netherlands.

Rohl, U., T. J. Bralower, R. D. Norris, and G. Wefer (2000), New chronology for the late Paleocene thermal maximum and its environmental implications, Geology, 28, 927-930.

Saarnisto, M., P. Huttunen, and K. Tolonen (1977), Annual lamination of sediments in Lake Lovojärvi, southern Finland, during the past 600 years, Ann. Bot. Fennici, 14, $35-45$.

Schiefer, E. (2006), Contemporary sedimentation rates and depositional structures in a montane lake basin, southern Coast Mountains, British Columbia, Canada, Earth Surf. Processes Landforms, 31, 1311-1324.

Schimmelmann, A., and C. P. Lange (1996), Tales of 1001 varves: A review of Santa Barbara Basin sediment studies, in Palaeoclimatology and Palaeoceanography From Laminated Sediments, edited by A. E. S. Kemp, Geol. Soc. Spec. Publ., 116, 12-14.

Schowengerdt, R. A. (1997), Remote Sensing: Models and Methods for Image Processing, 522 pp., Academic, New York.

Shanahan, T. M., J. T. Overpeck, C. W. Wheeler, J. W. Beck, J. A. Peck, J. W. King, and C. Scholz (2008), The formation of biogeochemical laminations in Lake Bosumtwi, Ghana and their usefulness as indicators of past environmental changes, J. Paleolimnol., in press.

Sieburth, J. M., and P. L. Donaghay (1993), Planktonic methane production and oxidation within the algal maximum of the pycnocline: Seasonal fine-scale observations in an anoxic estuarine basin, Mar. Ecol. Prog. Ser., 100, 3-15.

Snyder, J. A., A. Wernerand, and G. H. Miller (2000), Holocene glacier activity in a cirque, Western Spitsbergen, Svalbard: Sediment records from proglacial Linnevatnet, Holocene, 10, 555-563.

Stauffer, R. E., and D. E. Armstrong (1986), Cycling of iron, manganese, silica, phosphorous, calcium and potassium in two stratified basins of Shagawa Lake, Minnesota, Geochim. Cosmochim. Acta, 50, 215-229.

Sturm, M., and A. Matter (1978), Turbidites and varves in Lake Breinz (Switzerland): Deposition of clastic detritus by density currents, in Modern and Ancient Sediments, edited by A. Matter and M. E. Tucker, pp. 147-168, Blackwell, Oxford, U. K.

Suits, N. S., and R. T. Wilkin (1998), Pyrite formation in the water column and sediments of a meromictic lake, Geology, 26, 1099-1102.

Talbot, M. R., D. A. Livingstone, P. G. Palmer, J. Maley, J. M. Melack, G. Delibrias, and S. Gulliksen (1984), Preliminary results from sediment cores from Lake Bosumtwi, Ghana, Paleoecol. Africa, 16, 173-192.

Teranes, J. L., and S. M. Bernasconi (2000), The record of nitrate utilization and productivity limitation provided by delta N-15 values in lake organic matter-A study of sediment trap and core sediments from Baldeggersee, Switzerland, Limnol. Oceanogr., 45, 801-813.

Thunell, R. C., E. Tappa, and D. M. Anderson (1995), Sediment fluxes and varve formation in Santa Barbara Basin, offshore California, Geology, 23, 1083-1086.

Tian, J., T. A. T. A. Brown, and F. S. Hu (2005), Comparison of varve and ${ }^{14} \mathrm{C}$ chronologies from Steel Lake, Minnesota, USA, Holocene, 15, 510-517.

Tian, J., D. M. Nelson, and F. S. Hu (2006), Possible linkages of late-Holocene drought in the North American midcontinent to Pacific Decadal Oscillation and solar activity, Geophys. Res. Lett., 33, L23702, doi:10.1029/2006GL028169.

Tiljander, M., A. Ojala, T. Saarinen, and I. Snowball (2002), Documentation of the physical properties of annually laminated (varved) sediments at sub-annual to decadal resolution for environmental interpretation, Quat. Int., 88, 5-12.

Tipping, E., C. Woof, and D. Cooke (1981), Iron oxide from a seasonally anoxic lake, Geochim. Cosmochim. Acta, 45, 1419-1441.

Vekemans, B., K. Janssens, L. Vincze, A. Aerts, F. Adams, and J. Hertogen (1999), Automated segmentation of m-XRF image sets, $X$ Ray Spectrom., 26, 333-346.

Wilkin, R. T., and H. L. Barnes (1997a), Formation processes of framboildal pyrite, Geochim. Cosmochim. Acta, 61, 323-339.

Wilkin, R. T., and H. L. Barnes (1997b), Pyrite formation in an anoxic estuarine basin, Am. J. Sci., 297, 620-650.

Winter, T. C. (Ed.) (1997), Hydrological and biogeochemical research in the Shingobee river headwaters area, north-central Minnesota, Water-Resour. Invest. Proj. 96-4215, U.S. Geol. Surv., Denver, Colo.

Wright, H. E., I. Stefanova, J. J. Tian, T. A. Brown, and F. S. $\mathrm{Hu}$ (2004), A chronological framework for the Holocene vegetational history of central Minnesota: The Steel Lake pollen record, Quat. Sci. Rev., 23, 611-626. 